\title{
Using Fragility Curves for the Evaluation of Seismic Improvement of Steel Moment Frames
}

\author{
Hadi Faghihmaleki ${ }^{1, *}$, Hamid Roosta ${ }^{2}$, Ali Hooshmand Aini ${ }^{3}$, Elmira Khaksar Najafi ${ }^{1}$ \\ ${ }^{1}$ Department of Civil Engineering, Ayandegan Institute of Higher Education, Tonekabon, Iran. \\ ${ }^{2}$ Department of Civil Engineering, Nowshahr Branch, Islamic Azad University, Nowshahr, Iran. \\ ${ }^{3}$ Department of Civil Engineering, Roudbar Branch, Islamic Azad University, Roudbar, Iran. \\ * Corresponding Author, Email: h.faghihmaleki@gmail.com
}

Geliş Tarihi: 18.01.2016; Kabul Tarihi: 25.08.2016

\begin{tabular}{cl} 
& Abstract \\
\cline { 2 - 3 } $\begin{array}{c}\text { Keywords } \\
\text { seismic improvement }\end{array}$ & $\begin{array}{l}\text { There are numerous methods for buildings' seismic improvement, one of which is to increase the } \\
\text { lateral force demand. To do so, adding different types of frames or a shear wall in structures is quite }\end{array}$ \\
Steel moment frame & common as a new structural element. The present study selects three steel moment frame structures \\
ShF frame & with four, seven, and twelve stories, all of which have similar floor plans and are designed based on the \\
BRB frame & old seismic design code (UBC 1997 code), which is vulnerable in accordance with FEMA 356 code. For \\
seismic improvement Concentrically Braced Frame (CBF), Buckling Restrained Brace (BRB), and shear \\
time history dynamic \\
analysis
\end{tabular}$\quad \begin{aligned} & \text { wall have been used. The seismic performance level of the primary structure and improved structures } \\
& \text { were compared by means of seismic fragility curve. Earthquake intensity index is "PGA". Finally, by } \\
& \text { selecting an appropriate damage index, fragility curves of the original structure as well as the improved } \\
& \text { structures were presented and compared with a normal log distribution, the results of which was } \\
& \text { analyzed. }\end{aligned}$

\section{Using Fragility Curves for the Evaluation of Seismic Improvement of Steel Moment Frames}

\footnotetext{
Anahtar kelimeler

Titreşim gelişmesi

çelik moment

çerçeveler

CBF

BRB

yontulmuş duvar

dinamik analiz
}

\begin{abstract}
Özet
Bu çağlarda binalarin titreşimle iyi Olması için çoklu yollar var. Bu yollardan biri binani yan sertlikinin çok olmasıdır buna göre perde yada canlandırıcı yeni yapi elemanlari çok yaygındır. Bu çalişmada uç yapida dört,yedi,ve oniki. Katlarda çelik moment cevcevleri kalaninlmiştir ki her üç plani ortak zemindedir eski versiyonu bina titreşimi güçlendirilmiş duzenleme (UBC 1997code) tasarlanmıştır ki FEMA 356 düzenlemesine göre binalar çok savunmasız dir ve seçilmişdir binanin titreşim gelişmesine göre CFB ve $B R B$ ve perde bulabilmiştir sismik bina performans düzeyini ve geliştirilmiş binalari eğer ile kirilgan olduğunu binalar karşılaşırmış. PGA deprem şiddet indeksi seçilmiştir ve sonunda sismik kırılma ayarlari uygun yaralanma şiddeti şeçilerek asil bina ve geliştirilmiş bina karşılaştırilmiş ve sonuçları araştırılmıştir.
\end{abstract}

(C) Afyon Kocatepe Üniversitesi

\section{Introduction}

To evaluate buildings' performance, under the influence of earth movements, particularly in seismic regions, has always been an important subject. Thus, it is necessary to investigate the existing structural risk, in order to estimate collapse potential from an earthquake. In this work an efficient calculative method is proposed to estimate fragility curves, which are

suggested to be determined based on maximum story drift of a huge range of building damage with Life Safety (LS) performance, while considering the neural network [1 and 2]. Majd et al [3] used the 
development of reliable fragility curves based on two parameters of damage including "inter-storey drift" and "axial plastic deformation".

Özel and Güneyisi [4] studied fragility curve of RC frame, equipped with coaxial frame, using distribution functions of bi-parameter normal log that showed strengthening of Reinforced Concrete buildings with such frames improves their performance in case of an earthquake. Jong and Elnashai [5] presented the principles to develop fragility curves for concrete structures with disordered plans, determining an index to describe damage characteristics of irregular structures. Liao et al [6] described the process of buildings' collapse in seismic evaluation system, calculating the parameters, used when recognizing building damages. Lowes and Pagni [7] developed seismic fragility functions aiming to determine a method for repairing old reinforced concrete (RC) beam-column subassemblies by earthquake loading. Kapposet et al. [8] also presented a technique for assessing the vulnerability of reinforced concrete (RC) and unreinforced masonry (URM) structures. Elnashai and Jeong [9] presented an approach whereby a set of fragility relationships with known reliability is derived based on the fundamental response quantities of stiffness, strength and ductility. Lagaros [10] carried out a fragility assessment test on reinforced concrete structures by devising three different methods. Polat and Kircil [11] developed fragility curves for mid-rise RC frame buildings in Istanbul, which are designed according to Turkey's seismic design code, based on numerical simulations in accordance with the number of the stories of the buildings. In their study, Polat and Kirchil designed 3, 5, and 7 story buildings and employed incremental dynamic analysis (IDA) to measure the yielding and collapse capacity of the designed buildings under twelve artificial ground motions. According to the aptitude of the buildings, they produced fragility curves for the yielding and collapse capacities of the structures under lognormal distribution parameters on the basis of elastic pseudo spectral acceleration, Peak Ground Acceleration (PGA), and elastic spectral displacement. Afterwards, they employed regression analysis to determine the effect of the number of the stories of the buildings on fragility parameters. Their study disclosed that there was a reverse relationship between the number of the stories and fragility parameters.

The aim of the present study is to analyze the influence of Concentrically Braced Frames (CBF), Buckling Restrained Frames (BRF) and shear walls on the seismic performances of steel moment frame buildings. Analytical fragility curves create a function of PGA by means of time history nonlinear analysis to study the effect of various braces along with shear wall. In order to show fragility curves, bi-parameter distribution functions with normal log have been used. The estimated fragility curves, which correspond to the appropriate damage levels, are used for steel moment frame buildings. Moreover, the presented fragility curves could be used to determine potential damages of earthquakes and evaluate the effect of either buckling braces and shear wall for improvement.

\section{Damage Indices and Seismic Performance Surfaces}

In order to expand fragility curves, it is necessary to use some logical damage indices for each structural element. In columns and beams, "plastic hinges rotation" is widely done by the researchers, 
yet in brace elements "axial relative deformation" or "inter-story drift" is the appropriate index. In the present study, "axial plastic deformation" has been used in brace elements as damage index for the calculation of frames' fragility. In addition, 3 levels of low, average, and expanded could be taken into consideration for general damage in a building, which are usually regarded as Performance Level (PL) of a building against an earthquake, i.e. as a specific danger level. In FEMA 306 [12], these three levels are called Immediate Occupancy (IO), Life Safety (LS), and Collapse Prevention (CP), which are employed in the current study. Accordingly, whenever the selected damage index exceeds the corresponding rate, dependent on each of these three levels, it means that system fragility has taken place in that specific performance level.

\section{Modeling and Main Structure Analysis}

Three specific steel moment frame buildings with four, seven, and twelve stories, located in a region with high seismicity, were selected. The buildings were residential, measured in accordance to the old seismic design codes (UBC 97) [13]. All three buildings had common plans, with different heights. Fig. 1 illustrates floor plan as well as the intended frames. The gravity load contained dead and live loads. The dead load of the stories' floor load was $550 \frac{\mathrm{kg}}{\mathrm{m}^{2}}$; the live load, $200 \frac{\mathrm{kg}}{\mathrm{m}^{2}}$; and the roof's floor load, 150 $\frac{\mathrm{kg}}{\mathrm{m}^{2}}$. Other kinds of loading, such as wind load or snow load, were not taken into account. Moreover, soil-structure interaction was not considered as well with columns' bases assumed to be in the floor. The stories' height was considered to be 3.2 meters.

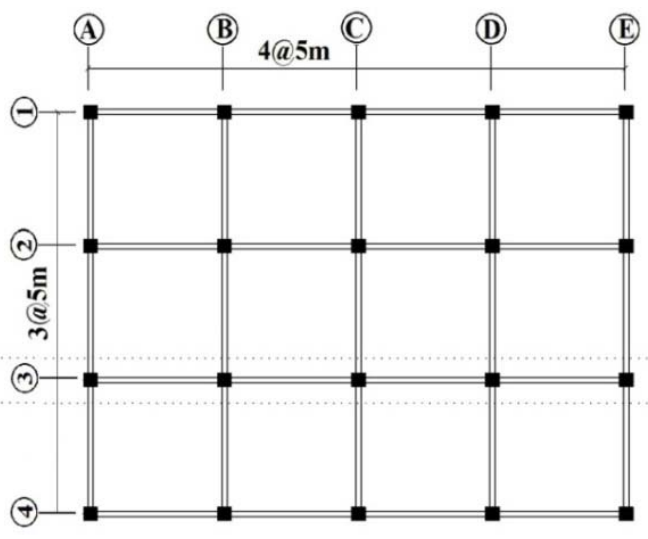



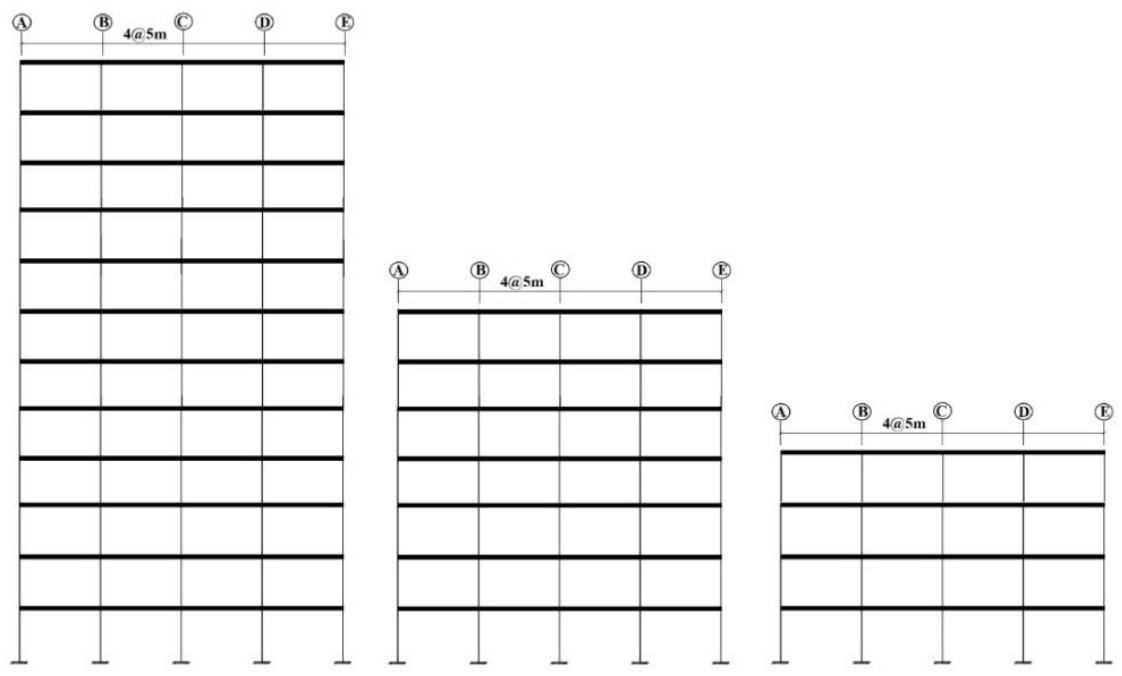

Figure 1. Floor plans and the considered frames (Frame 3) for the study.

Compressive strength of roof's concrete was $210 \frac{\mathrm{Kg}}{\mathrm{Cm}^{2}}$ and concrete slab thickness in the floors, $15 \mathrm{~cm}$. The table, below, demonstrates column and beam sections, used in this building.

Table 1. Sections, used in the considered structures.

\begin{tabular}{ccc|ccc}
\hline Story & Columns & Beams & Story & Columns & Beams \\
\hline 1 & 2IPE600 & IPE450 & 7 & 2IPE450 & IPE360 \\
2 & 2IPE550 & IPE400 & 8 & 2IPE450 & IPE360 \\
3 & 2IPE550 & IPE400 & 9 & IPE600 & IPE450 \\
4 & 2IPE500 & 2IPE360 & 10 & IPE400 & IPE320 \\
5 & 2IPE500 & 2IPE360 & 11 & IPE330 & IPE270 \\
6 & 2IPE500 & 2IPE360 & 12 & IPE300 & IPE240 \\
\hline
\end{tabular}

Each element is modeled with an individual column/beam element, whereas the frames have stable rigid connections and abutments, which make an appropriate balance between calculation accuracy and costs [14]. The impact of gravitational forces and second order effects are taken into account and studied in accordance with geometrical nonlinear considerations. Steel behavior modeling program attributed a kinematic stress-strain curve (as shown in fig. 2) for structural members by means of steel materials in SeismoStruct Software. A transition curve is presented for these materials at the intersection of the first and second tangent in order to prevent sudden 
changes in local rigidity matrices, generated by the elements, as well as to ascertain a straight and smooth transition between elastic and plastic zones. A strain hardening module of $2 \% E$ and an ultimate strain of $4 \%$ were considered for member behavior within non-elastic transformation zone. Fig. 2 illustrates structural behavior with structural steel characteristics. For beams, columns, and frames, nonlinear column and beam elements were used, combined with cross sections, in order to do an accurate modeling of them.

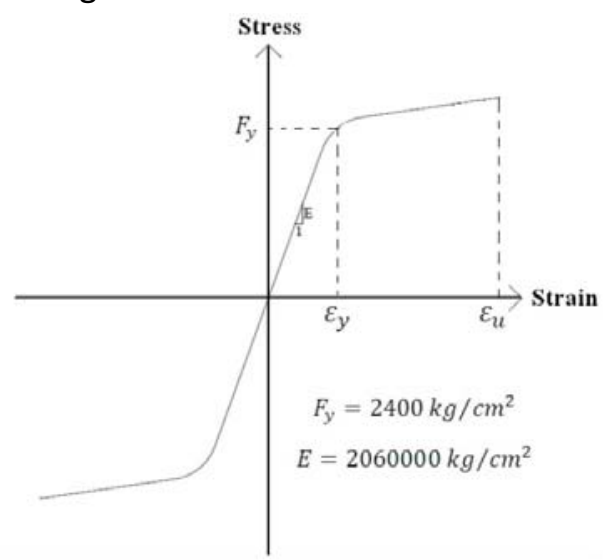

Figure 2. Structural steel behavior.

Initially, the considered structures were calculated in SeismoStruct V.6 [15], while taking into account AISC-1989b code, i.e. the shear force and coefficient of earthquake were used in accordance with this code. Afterwards the building in question, was recalculated based on the seismic provisions for steel structures (ANSI/AISC 341-10) [16], showing that both the tension and story drift have exceeded the allowed range of the code. Such circumstances show that this building does not have an appropriate performance against secondary displacements, based on the ANSI/AISC 34110 code, thus it needs seismic improvement. Based on the FEMA 356 code [17], buildings which have gone through seismic design in accordance to their importance and based on the ANSI/AISC 341-10 code, does not need any evaluation and seismic improvement. In the present research, based on the mentioned results it is seen that the considered building needs seismic improvement in terms of danger level as well as required performance level. Some changes in the ANSI/AISC 341-10 code have caused the estimation amount of earthquake-caused secondary force to be a different amount; therefore, structures, modeled with AISC-1989b code, are not satisfactory in the same circumstances, based on ANSI/AISC 341-10 code, and need seismic improvement.

\section{Improved Structures}

The expansion of efficient seismic improvement systems is necessary to improve buildings' seismic performance before they are exposed to an earthquake. This research uses and studies three systems of $C B F, B R B$, and shear wall to achieve the best performance level. Fig. 3 shows reinforced steel moment frames. Table 2 presents the properties of shear wall in each storey.

Table 2. The properties of the shear walls used.

\begin{tabular}{ccccc}
\hline $\begin{array}{c}\text { Reinforcement } \\
\text { ratio }(\boldsymbol{\rho})\end{array}$ & $\begin{array}{c}\text { Reinforceme } \\
\text { nt }\end{array}$ & $\begin{array}{c}\text { Thickness of } \\
\text { wall }(\mathbf{c m})\end{array}$ & $\begin{array}{c}\text { The storey of } \\
\text { interest }\end{array}$ & $\begin{array}{c}\text { Shear wall } \\
\text { name }\end{array}$ \\
\hline 0.01 & $\phi 22 @ 15 \mathrm{~cm}$ & 35 & $1,2,3$ & W1 \\
\hline
\end{tabular}




\begin{tabular}{ccccc}
\hline 0.007 & $\phi 18 @ 15 \mathrm{~cm}$ & 35 & $4,5,6,7,8$ & W2 \\
0.0035 & $\phi 16 @ 15 \mathrm{~cm}$ & 30 & $9,10,11,12$ & W3 \\
\hline
\end{tabular}
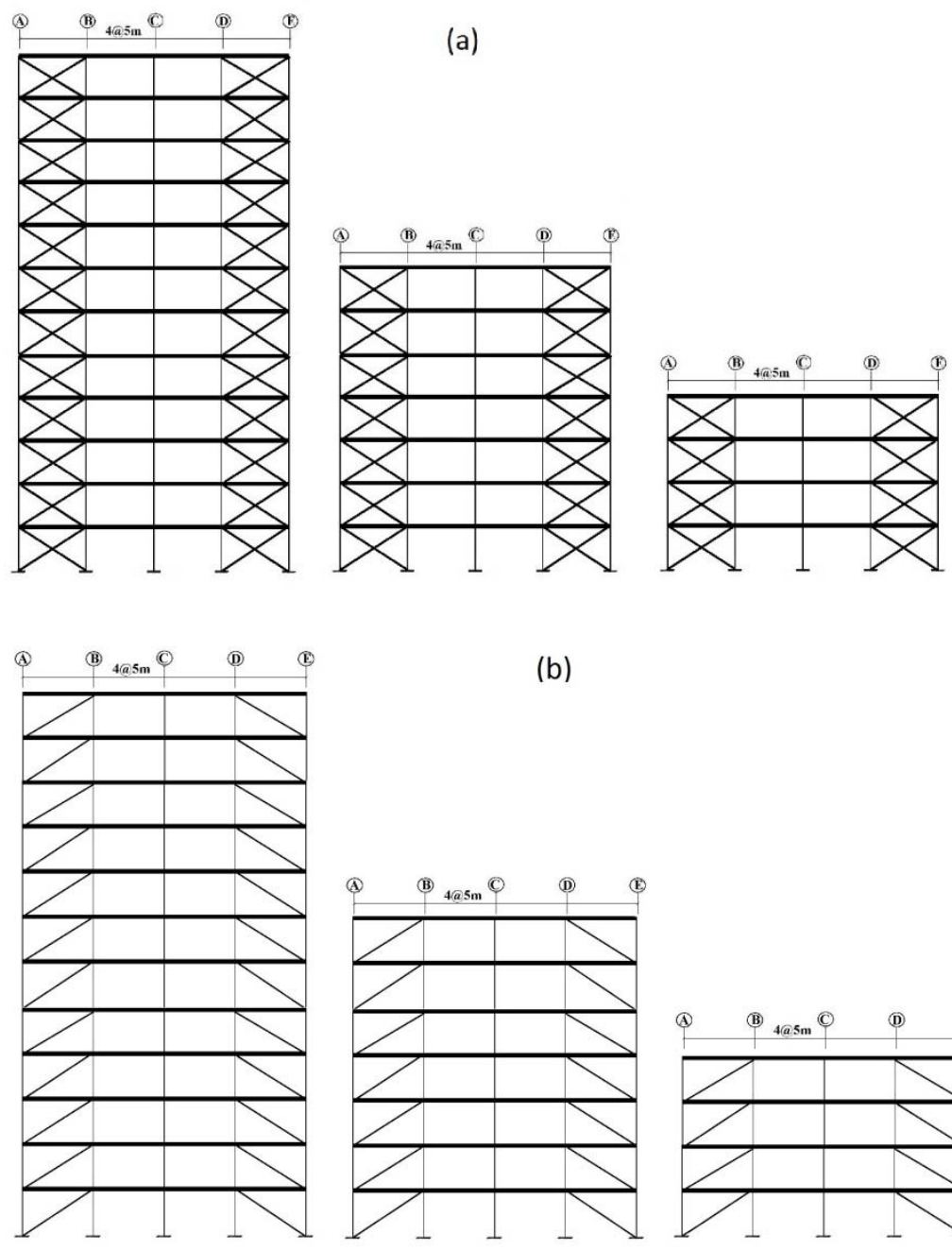

(b)
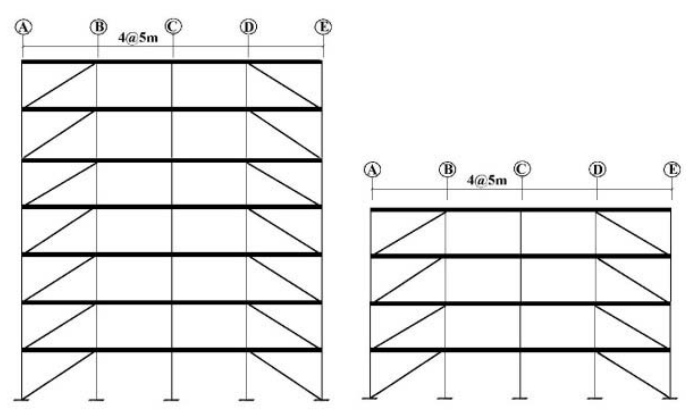

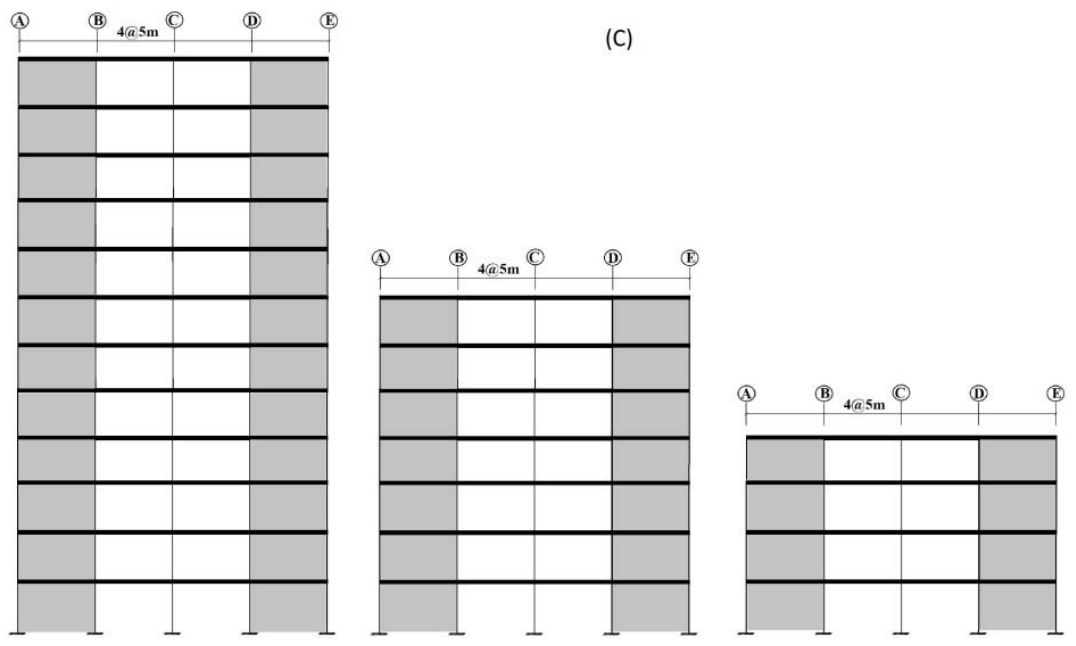

Figure 3. Seismic improvement of the considered steel moment frame: a) concentrically-braced frame, b) $\mathrm{BRB}$, and c) shear wall.

\subsection{Buckling Restrained Frame (BRB)}

A weakness of common frames is the difference between tensile and compressive strengths and, consequently, decline in the resistance of such frames when encountering cyclic loading. Yet in BRB, the core should be designed in a way that both compression and tension submit. In order to prevent ultimate buckling in compression, the core is put within a steel tube and the space between the tube and steel core is filled with mortar or concrete. Before pouring the mortar, a non-sticky mortar is put in the empty space between core and mortar. Fig. 4 compares hysteric behavior of BRB with typical buckling braces. If the resistance mechanism in buckling is in an appropriate size, the core can flow in the compression and show similar compressive and tensile strengths with ordered hysteresis behavior up to strains, beyond $2 \%$ [18].

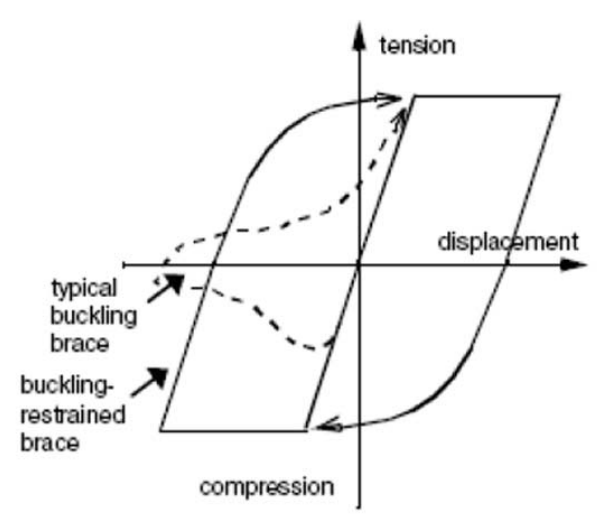

Figure 4. Comparison of typical buckling braces with BRB [19 and 20].

In this research, the size of core and tube, and crust thickness of BRB are $153 \times 19\left(\mathrm{~mm}^{2}\right)$ and $3 \mathrm{~mm}$ respectively. The central core is considered to be normal-strength steel ST37 and the surrounding steel crust is highstrength steel ST52. Also the used concrete is the same usual concrete with compression strength of $21 \mathrm{Mpa}$. There is $2.5 \mathrm{~mm}$ of empty space between the central core and concrete/mortar in each side. The 
mentioned distance is in effect the same thickness of the separating layer so that the core, under the effect of imposed force, enters higher modes, and, consequently, the buckling brace shows better behavior in cyclic loadings. The middle concrete and steel crust are in continuously contact.

\subsection{Concentrically Braced Frame (CBF)}

$\mathrm{CBF}$ members in all stories have equal cross sections and material characteristics. They are considered as rectangular hollow sections, $15 \mathrm{~cm}$ wide and $4 \mathrm{~mm}$ thick (Figure 5). Therefore, all these frames possess average thinness and their effective length coefficient is considered as one. Special considerations are taken into account for connection between steel frames and shear walls with steel member (shear connection). There have been several experiential and numerical studies to deal with these connections [21, 22].

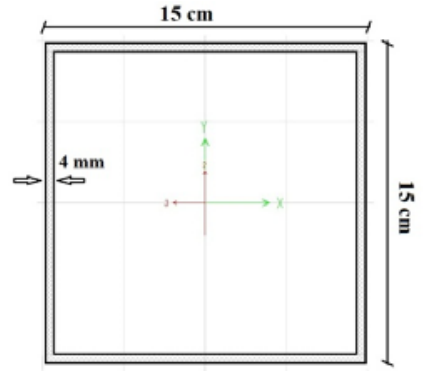

Fig. 5. CFB element cross-section.

\section{Time History Dynamic Analysis}

Seismic response of the main structure as well as the improved ones is made in order to present fragility curve by means of time history dynamic analysis. Column and beam elements are modeled as nonlinear frame elements, by the definition of plastic hinges at both tips of the columns and beams. In order to carry out the intended analysis, SeismoStruct V. 6 has been used. Table 3 shows the earthquake records, used in this research, which have been taken from PEER database. Thirty earthquake records have a magnitude between 6.5 and 7 and the soil type is $C$ and $D$. The distance of earthquake center to the building is between 15 and 30 $\mathrm{km}$. Ground acceleration records for each earthquake have been scaled, corrected, and filtered by SeismoSignal V5.1 [23].

Table 3. Used earthquake records.

\begin{tabular}{cccccc}
\hline NO & EVENT & STATION & NO & EVENT & STATION \\
\hline 1 & $\begin{array}{c}\text { Imperial Valley } \\
1979\end{array}$ & Chihuahua & 16 & Northridge, 1994 & LA, Baldwin Hills \\
& Imperial Valley & Chihuahua & 17 & Imperial Valley, & El Centro Array \#12 \\
1979 & Hollywood & 18 & Loma Prieta, 1989 & Anderson Dam \\
& Northridge 1994 & Storage & & & Downstream \\
& & Lake Hughes \#1 & 19 & Loma Prieta, 1989 & Anderson Dam \\
4 & San Fernando & & & Downstream \\
\hline
\end{tabular}




\begin{tabular}{|c|c|c|c|c|c|}
\hline 5 & $\begin{array}{c}\text { San Fernando } \\
1971\end{array}$ & $\begin{array}{c}\text { Hollywood Stor } \\
\text { Lot }\end{array}$ & 20 & Loma Prieta, 1989 & Agnews State Hospital \\
\hline 6 & $\begin{array}{l}\text { Super Stition } \\
\text { Hills } 1987\end{array}$ & $\begin{array}{c}\text { Wildlife } \\
\text { Liquefaction } \\
\text { Arrey }\end{array}$ & 21 & Loma Prieta, 1989 & $\begin{array}{l}\text { Anderson Dam } \\
\text { Downstream }\end{array}$ \\
\hline 7 & $\begin{array}{l}\text { Super Stition } \\
\text { Hills } 1987\end{array}$ & $\begin{array}{c}\text { Wildlife } \\
\text { Liquefaction } \\
\text { Arrey }\end{array}$ & 22 & Loma Prieta, 1989 & $\begin{array}{l}\text { Coyote Lake Dam } \\
\text { Downstream }\end{array}$ \\
\hline 8 & $\begin{array}{l}\text { Super Stition } \\
\text { Hills } 1987\end{array}$ & $\begin{array}{c}\text { Salton Sea } \\
\text { Wildlife Refuge }\end{array}$ & 23 & $\begin{array}{c}\text { Imperial Valley, } \\
1979\end{array}$ & Cucapah \\
\hline 9 & $\begin{array}{l}\text { Super Stition } \\
\text { Hills } 1987\end{array}$ & Plaster City & 24 & Loma Prieta, 1989 & Sunnyvale Colton Ave \\
\hline 10 & $\begin{array}{l}\text { Super Stition } \\
\text { Hills } 1987\end{array}$ & $\begin{array}{l}\text { Calipatria Fire } \\
\text { Station }\end{array}$ & 25 & $\begin{array}{c}\text { Imperial Valley, } \\
1979\end{array}$ & El Centro Array \#13 \\
\hline 11 & Landers 1992 & Barstow & 26 & $\begin{array}{c}\text { Imperial Valley, } \\
1979\end{array}$ & $\begin{array}{c}\text { Westmoreland Fire } \\
\text { Station }\end{array}$ \\
\hline 12 & Cape Mendocino & Rio Dell Overpass & 27 & Loma Prieta, 1989 & Sunnyvale Colton Ave \\
\hline 13 & $\begin{array}{c}\text { Cape Mendocino } \\
1992\end{array}$ & Rio Dell Overpass & 28 & $\begin{array}{c}\text { Imperial Valley, } \\
1979\end{array}$ & El Centro Array \#13 \\
\hline 14 & Coalinga 1983 & $\begin{array}{c}\text { Parkfield - Fault } \\
\text { Zone } 3\end{array}$ & 29 & $\begin{array}{c}\text { Imperial Valley, } \\
1979\end{array}$ & $\begin{array}{c}\text { Westmoreland Fire } \\
\text { Station }\end{array}$ \\
\hline 15 & $\begin{array}{c}\text { Whittier } \\
\text { Narrows } 1987\end{array}$ & Beverly Hills & 30 & Loma Prieta, 1989 & Hollister Diff. Array \\
\hline
\end{tabular}

\section{Expansion of Fragility Curves}

Fragility curves are one of the main parameters when evaluating seismic damage, which makes potential seismic performance of different buildings possible. In other words, it shows the vulnerability of steel buildings and the improved ones via vulnerability functions, called fragility curves. In fact fragility curves are conditional probabilities that show the possibility of reaching or exceeding a damage level (in this paper, different performance levels of FEMA 306 instruction) under earthquake intensity index (PGA in this paper). This probability could be demonstrated as below:
$P[D=X]=\varphi\left[\frac{1}{\beta} \ln \left(\frac{X}{\mu}\right)\right]$

In which $\phi$ is the normal standard cumulative distribution; $X$, the earthquake intensity index that has a normal distribution log; $M$, the average amount of earthquake intensity index in which the structure reaches the threshold of damage levels, defined by means of legal drift proportions; and $\beta$ the standard deviation of natural logarithm of earthquake intensity index at varying damage levels. In order to calculate the fragility parameters of $\beta$ and $\mu$ by doing time history dynamic analyses for each structure, a set of maximum damage indices, 
in relation to PGA are obtained. It should be noted here that PGA is not a complete index to explain earthquake intensity, for it does not give specific information, concerning frequency or persistence time of the earthquake. Yet due to its simplicity and since there is no other individual index, suitable for non-linear dynamic issues without resistance decrease, it is still in use [24, 25 and 26].

Standard deviation and average earthquake intensity indices for different damage levels are obtained by doing a linear regression. Fig. 6 shows linear regressions for $C B F, B R B$, and shear wall structures with the main building, being consisted of eight stories as sample. It can be seen from Fig. 6 that correlation coefficient of $R^{2}$ is between 0.90 and 0.96 , which shows a relatively good linearity.

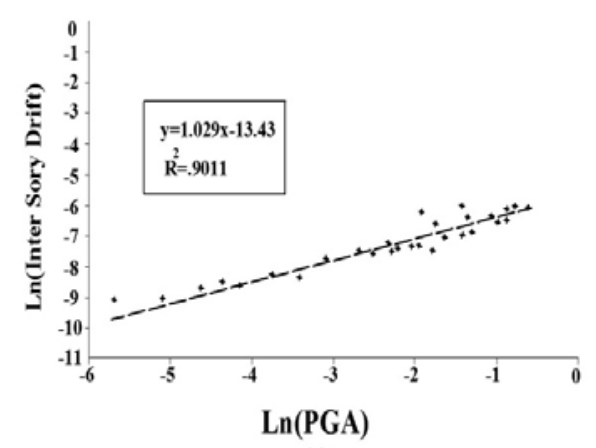

(a)

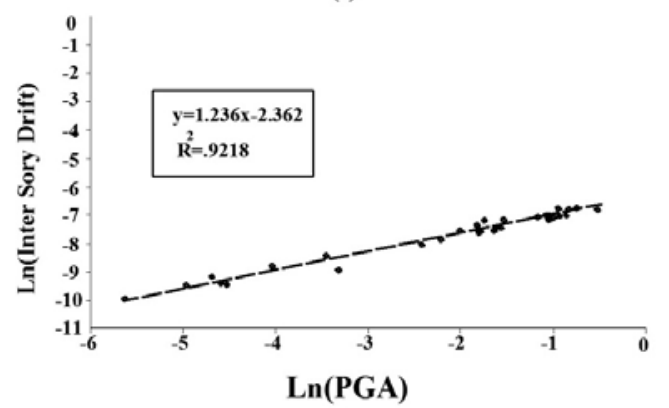

(b)

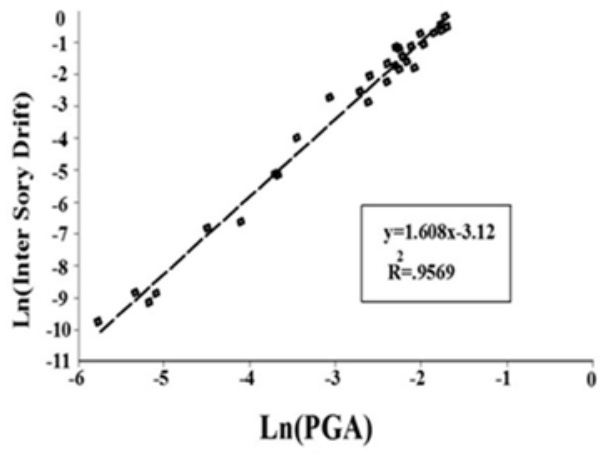

(c)

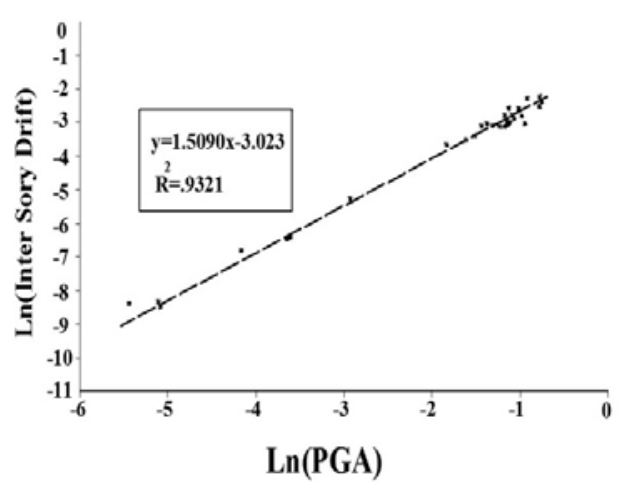

(d)

Figure 6. Linear regression: a) main frame, b) CBF-improved frame, c) BRB-improved frame, and d) shear wall-improved frame.

Table 4 shows the fragility curve parameters of standard deviation and average earthquake intensity index, distributed as a normal log, in comparison to PGA for damage levels.

Table 4. Fragility parameters. 


\begin{tabular}{|c|c|c|c|c|c|c|c|}
\hline & & \multicolumn{6}{|c|}{ Damage Level } \\
\hline \multicolumn{2}{|c|}{ Building Type } & \multicolumn{2}{|l|}{10} & \multicolumn{2}{|l|}{ LS } & \multicolumn{2}{|l|}{$\mathrm{CP}$} \\
\hline & & $M$ & $\beta$ & $M$ & $\beta$ & $M$ & $\beta$ \\
\hline & 4-Story & 0.436 & 0.463 & 0.574 & 0.693 & 0.654 & 0.932 \\
\hline \multirow[t]{2}{*}{ Original } & 7-Story & 0.578 & 0.863 & 0.412 & 0.745 & 0.745 & 0.756 \\
\hline & 12-Story & 0.726 & 0.123 & 0.741 & 0.753 & 0863 & 0.632 \\
\hline \multirow{3}{*}{$\begin{array}{l}\text { CBF Brace } \\
\text { Frame }\end{array}$} & 4-Story & 0.869 & 0.456 & 0.863 & 0.357 & 0.889 & 0.812 \\
\hline & 7-Story & 0.902 & 0.563 & 0.896 & 0.412 & 0.901 & 0.634 \\
\hline & 12-Story & 0.896 & 0.212 & 0.841 & 0.523 & 0.923 & 0.451 \\
\hline \multirow{4}{*}{$\begin{array}{l}\text { BRB Brace } \\
\text { Frame }\end{array}$} & 4-Story & 0.871 & 0.369 & 0.901 & 0.322 & 0.903 & 0.654 \\
\hline & & & & & & & \\
\hline & 7-Story & 0.911 & 0.623 & 0.898 & 0.398 & 0.937 & 0.693 \\
\hline & 12-Story & 0.926 & 0.333 & 0.910 & 0.436 & 0.968 & 0.563 \\
\hline \multirow{3}{*}{$\begin{array}{l}\text { Shear Wall } \\
\text { Frame }\end{array}$} & 4-Story & 0.876 & 0.361 & 0.836 & 0.214 & 0.964 & 0.508 \\
\hline & 7-Story & 0.932 & 0.652 & 0.952 & 0.325 & 0.987 & 0.740 \\
\hline & 12-Story & 0.951 & 0.354 & 0.912 & 0.258 & 0.988 & 0.367 \\
\hline
\end{tabular}

Fig. 7 to 10 show expanded fragility curves for the main building and the improved ones. The curves, presented in this study, show that for all damage levels fragility curves have almost similar graphs but with different amounts. This means that the intensity of reaching a certain damage level (for example Immediate Occupancy (IO), Life Safety (LS), or Collapse Prevention (CP)) after improvement than bigger than before. What is more, with equal earthquake intensity, improved structures have less damage levels than before the improvement.

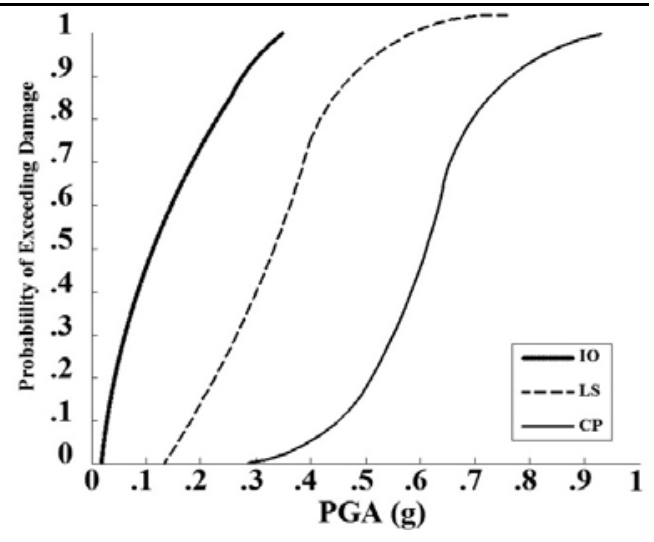

Figure 7. Fragility curve of the main structure (7-story model) with different damage levels. 

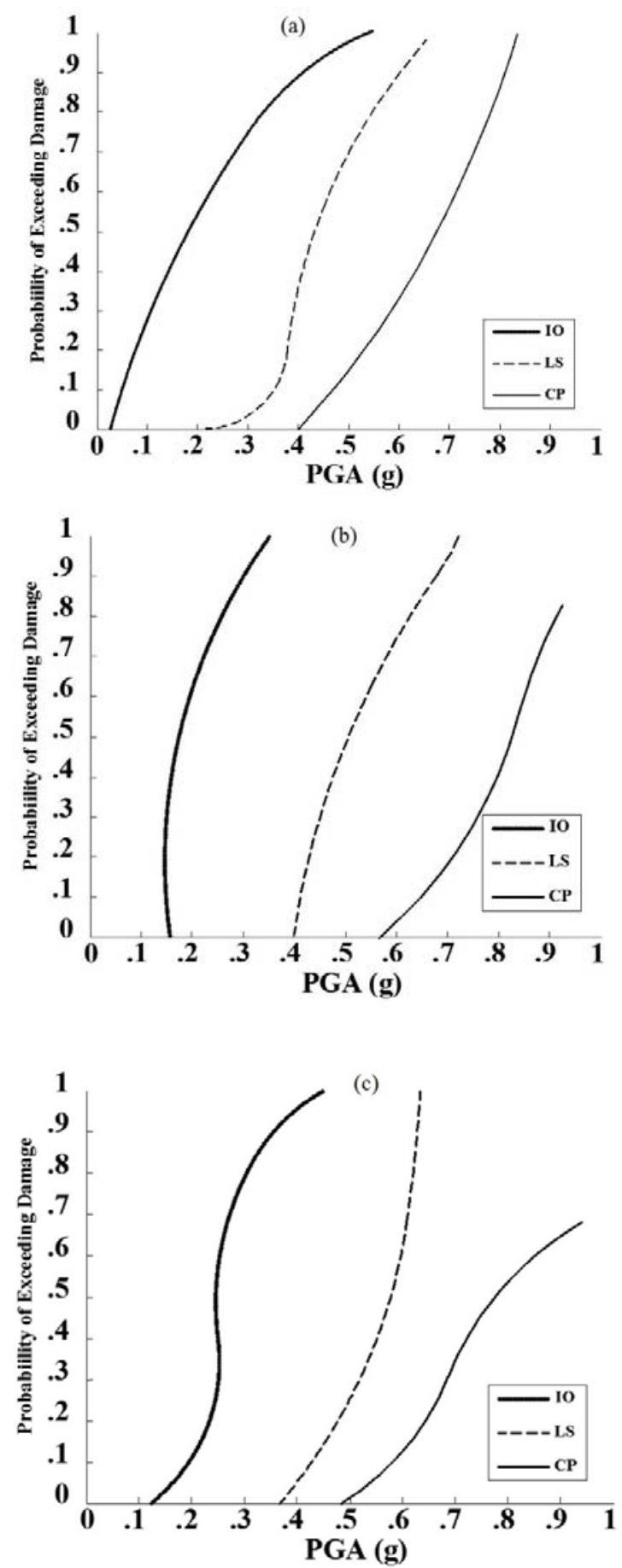

Figure 8. Fragility curves of CBF with different damage levels. A) 4-story model, b) 7-story model, and c) 12story model.
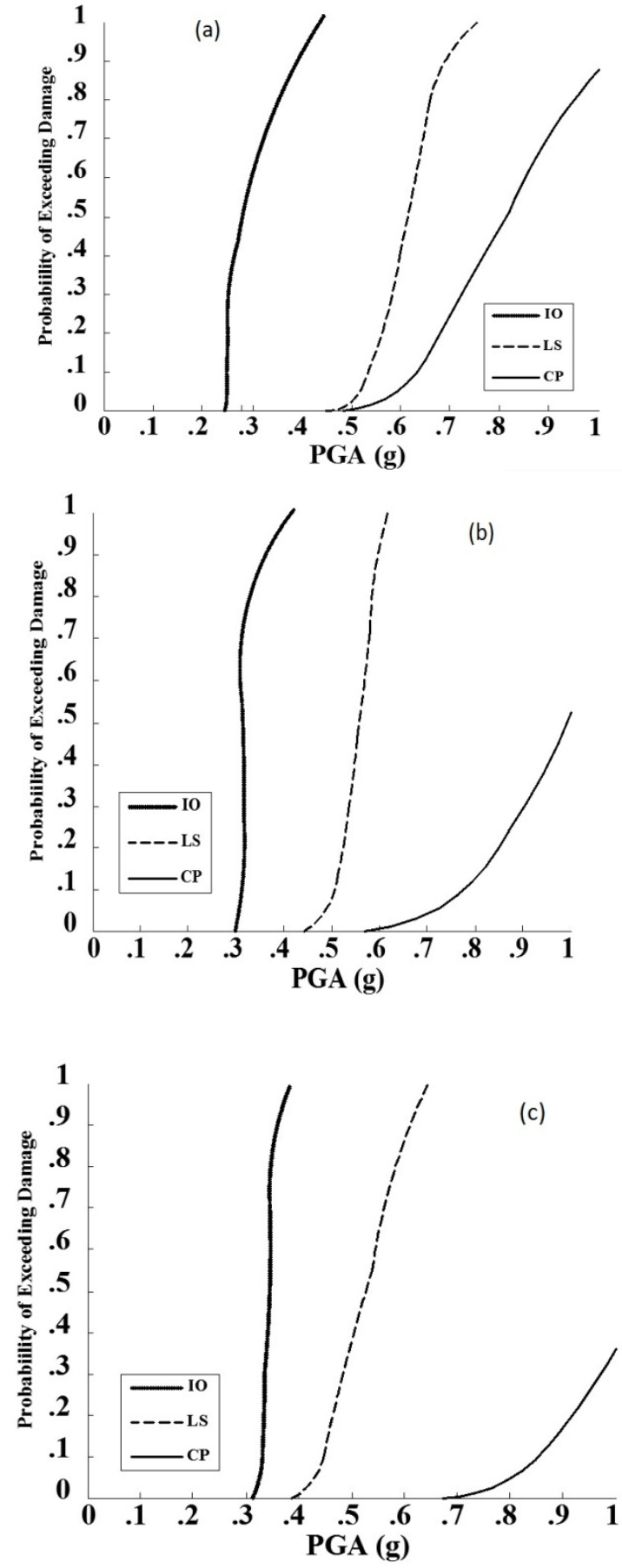

Figure 9. Fragility curves of BRB with different damage levels: a) 4-story model, b) 7-story model, and c) 12story model. 

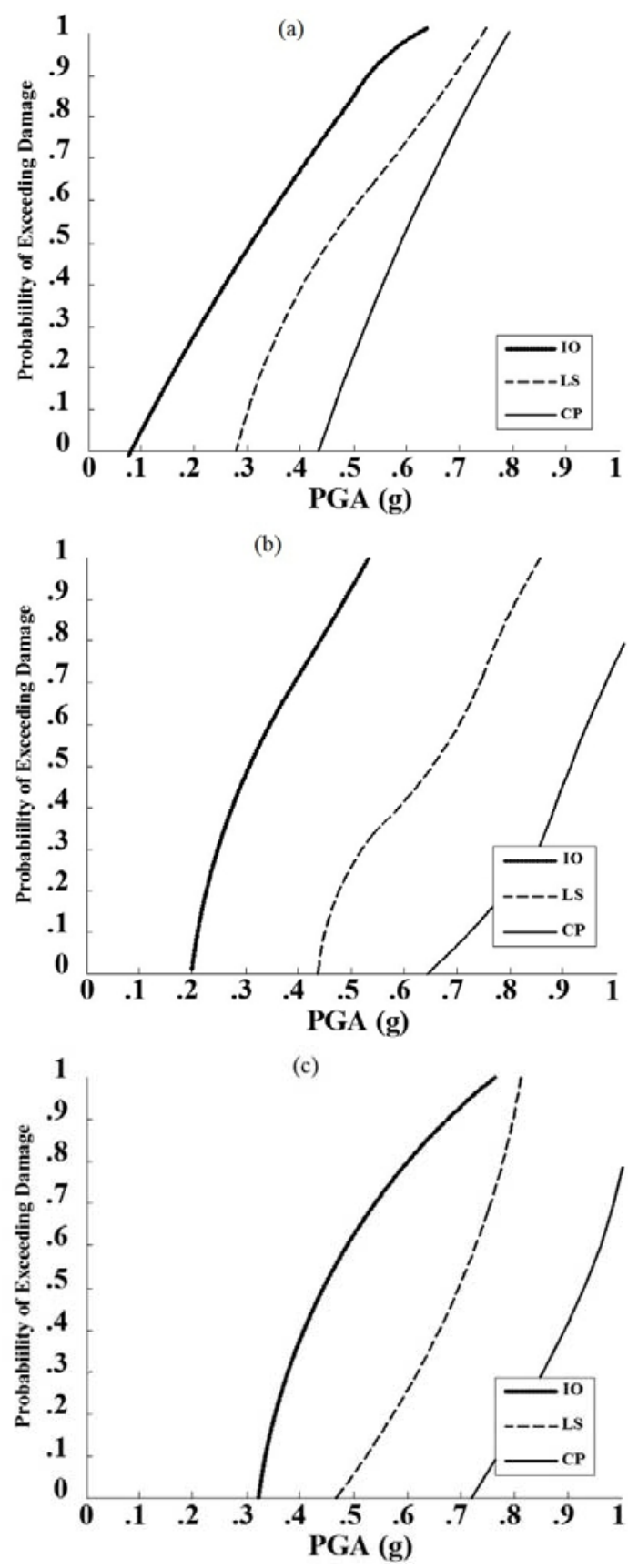

Figure 10. Fragility curve of shear wall frame with different damage levels: a) 4-story model, b) 7-story model, and c) 12-story model.

Considering the fragility curves of the main frame and the improved ones, it can be seen that firstly as the shock severity of earthquake increases, buildings' damage level changes so that for specific maximum earthquake severity for each building, it approaches collapse prevention; secondly, it is observed that with small PGA changes, damage levels change a lot, i.e. small changes of PGA amounts cause considerable change in damage level which is related to the uncertainty that depends on response range. Such uncertainties in the range of responses increase with PGA changes and the nonlinear behavior becomes more significant. Since the changes between distribution for each type of the buckling braces as well as the shear wall are very insignificant, for their performance comparison, the amount of standard deviation and average fragility parameters are calculated which have been presented in Table 4 .

\section{Conclusion}

This study showed the fragility analysis of a steel moment frame building before and after improvement with Concentrically-Braced Frame (CBF), Buckling Restrained Brace (BRB), and shear wall. Analytical fragility curves create a function of PGA by means of time history nonlinear analysis to study the effect of various braces along with shear wall. In order to show fragility curves, bi-parameter distribution functions with normal log have been used. The estimated fragility curves, which correspond to the mentioned damage levels, are used for steel moment frame buildings. Moreover, the presented fragility curves could be used to determine potential damages of earthquakes and evaluate the effect of either buckling braces and shear wall for improvement. According to the results in this study, it is understood that based on PGA amounts, the simulated fragility curves show an advance after improvement with either of the buckling braces or shear wall than before this improvement. Yet based on fragility analysis of bucking brace frames and shear wall, implemented as a tool to improve and reinforce the original structure, one can claim that the shear wall has a more suitable effect in secondary rigidity increase and, eventually, general seismic improvement of the structure, compared to $\mathrm{CBF}$ and BRB. Also between the two buckling braces, $B R B$ has more suitable seismic performance than CBF under the effect of seismic load, which is due to its symmetrical hysteresis cycle in tension and compression. This fact is observed in all stories of 
the sample, but it should be noted here that this study is a case analysis and limited to the samples. In order to achieve a general conclusion one has to increase the number of samples (for instance comparing the way of secondary elements' distribution, the impact of increasing the openings, different materials of the samples, etc.).

\section{Reference}

[1] Mitropoulou, C.C., and Papadrakakis, M., (2011). Developing fragility curves based on neural network IDA predictions. Journal of Engineering Structures, 33, 3409-3421.

[2] Khaloo, A., Nozhati, S., Masoomi, H., and Faghihmaleki, H., (2016). Influence of earthquake record truncation on fragility curves of RC frames with different damage indices. Journal of Building Engineering, 7, 23-30.

[3] Majd, M., Hosseini, and Amini, M. A., (2012). Developing Fragility Curves for Steel Building with X-Bracing by Nonlinear Time History Analyses. 15th World Conference Earthquake Engineering, Lisboan.

[4] Özel, A.E., and Güneyisi, E.M., (2011). Effects of eccentric steel bracing systems on seismic fragility curves of mid-rise $\mathrm{R} / \mathrm{C}$ buildings: $A$ case study. Journal of Structural Safety, 33, 82-95.

[5] Jong, S.H., and Elnashai, A.S., (2005). Analytical assessment of an irregular RC frame for full-scale 3D pseudo dynamic testing - Part I: Analytical model verification. Journal of Earthquake Engineering, 9, 95-128.

[6] Liao, W., Loh, C.H., and Tsai, K.C., (2006). Study on the fragility of building structures in Taiwan. Journal of Natural Hazards, 37,5569.

[7] Pagni, C.A, and Lowes, L.N., (2006). Fragility Functions for Older Reinforced Concrete Beam-Column Joints. Journal of Earthquake Spectra, 22, 215-38.

[8] Kappos, A.J., Panagopoulos, G., Panagiotopoulos, C., and Penelis, G., (2006). $A$ hybrid method forth vulnerability assessment of R/C and URM buildings. Journal of Bulletin Earthquake Engineering, 4, 391-413.

[9] Jeong, S.H., and Elnashai, A.S., (2007). Probabilistic fragility analysis parameterized by fundamental response quantities. Journal of Engineering Structure, 29, 1238-1251.

[10] Lagaros, N.D., (2008). Probabilistic fragility analysis of RC buildings designed with different rules. Journal of Earthquake Engineering and Engineering Vibration, 7, 45-56.

[11] Kircil, M.S., and Polat, Z., (2006). Fragility analysis of mid-rise $\mathrm{R} / \mathrm{C}$ frame buildings. Journal of Engineering Structures, 28, 13351345.

[12] FEMA 306., (1998). Evaluation Of Earthquake Damaged Concrete And Masonry Wall Buildings. Federal Emergency Management Agency, Washington, DC.

[13] UBC., (1997). Uniform Building Code, International Conference of Building Official,. Whittier, California, USA

[14] Fragiadakis, M., Papadrakakis, M., (2008). Modeling analysis and reliability of seismically excited structures: computational issues. International Journal of Computational Methods. 5, 483-511.

[15] SeismoSoft, (2012). SeismoStruct - A computer program for static and dynamic nonlinear analysis of framed structures.

[16] Seismic Provisions for Steel Structures (ANSI/AISC 341-10), (2010).

[17] FEMA 356., (2006). Prestandard and commentary for the seismic rehabilitation of buildings. Federal Emergency Management Agency, Washington, D.C.

[18] Abdollahzadeh, G., and Banihashemi., M.R., (2013). Response modification factor of dual moment resistant frame with buckling restrained brace (BRB). Journal of Steel Composite Structure, 14, 621 - 636.

[19] Abdollahzadeh, G., and Faghihmaleki, H., (2014). Response modification factor of SMRF improved with EBF and BRBs. Journal 
of Advanced Research in Dynamical and Control Systems, 6, 42-55.

[20] Jamnani, H.H., Abdollahzadeh, G., and Faghihmaleki, H., (In Press). Seismic Fragility Analysis of Improved RC Frames Using Different Type of Bracing. Journal of Engineering Science and Technology.

[21] Mazzolani, F.M., (2008). Innovative metal systems for seismic upgrading of RCstructures. Journal of Contracture Steel Research, 64, 882-895.

[22] D’Aniello, M., Corte G. D., Mazzolani F.M., (2006). Seismic upgrading of RC buildingsby steel eccentric braces: experimental results vs. numerical modeling. In:Proceedings of the 5th international conference on behavior of steel structures in seismic areas.

[23] Seismosignal, (2012). Earthquake Engineering Software Solutions, Version 5.1.0

[24] Symth, A., Altay, G., Deodatis, G., Erdik, M., Franco, G., and Gülkan, P., (2004) Probabilistic benefit-cost analysis for earthquake damage mitigation: evaluating measures for apartment houses in Turkey. Journal of Earthquake Spectra, 20,171-203.

[25] Faghihmaleki, H., Nejati, F., and Masoumi, H., (In Press). In Vitro Evaluation of Additives Allowed for High Strength Concrete (HSC) and Foam Concrete. Pamukkale University Journal of Engineering Sciences.

[26] Abdollahzadeh, G., and Faghihmaleki, H., (2016). Effect of seismic improvement techniques on a structure in seismicexplosive probabilistic two-hazard risk. International Journal of Structural Engineering, 7, 314-331. 